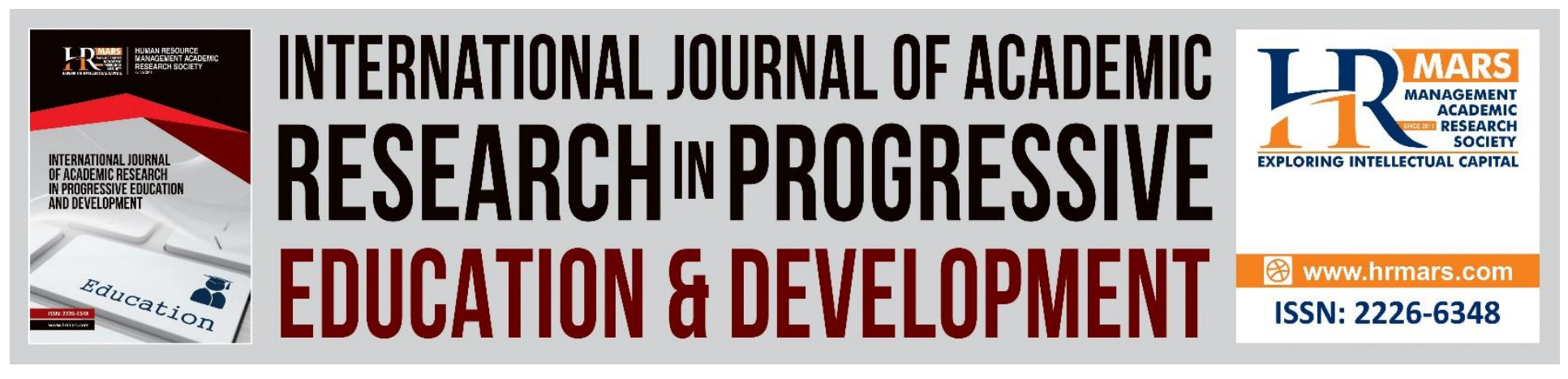

\title{
Learning Organizational Model in the 21th Century Classroom at Sultan Mahmud Science Secondary School in Terengganu, Malaysia
}

Mazni Salleh, Aminuddin Jusoh, Rahimah Embong, Mustafa Mamat

To Link this Article: http://dx.doi.org/10.6007/IJARPED/v7-i4/5334 DOI: 10.6007/IJARPED/v7-i4/5334

Received: 18 Oct 2018, Revised: 30 Nov 2018, Accepted: 04 Jan 2019

Published Online: 10 Jan 2019

In-Text Citation: (Salleh, Jusoh, Embong, \& Mamat, 2018)

To Cite this Article: Salleh, M., Jusoh, A., Embong, R., \& Mamat, M. (2018). Learning Organizational Model in the 21th Century Classroom at Sultan Mahmud Science Secondary School in Terengganu, Malaysia. International Journal of Academic Research in Progressive Education and Development, 7(4), 410-426.

Copyright: (C) 2018 The Author(s)

Published by Human Resource Management Academic Research Society (www.hrmars.com)

This article is published under the Creative Commons Attribution (CC BY 4.0) license. Anyone may reproduce, distribute, translate and create derivative works of this article (for both commercial and non-commercial purposes), subject to full attribution to the original publication and authors. The full terms of this license may be seen at: http://creativecommons.org/licences/by/4.0/legalcode

Vol. 7, No. 4, 2018, Pg. 410 - 426

http://hrmars.com/index.php/pages/detail/IJARPED

JOURNAL HOMEPAGE

Full Terms \& Conditions of access and use can be found at http://hrmars.com/index.php/pages/detail/publication-ethics 


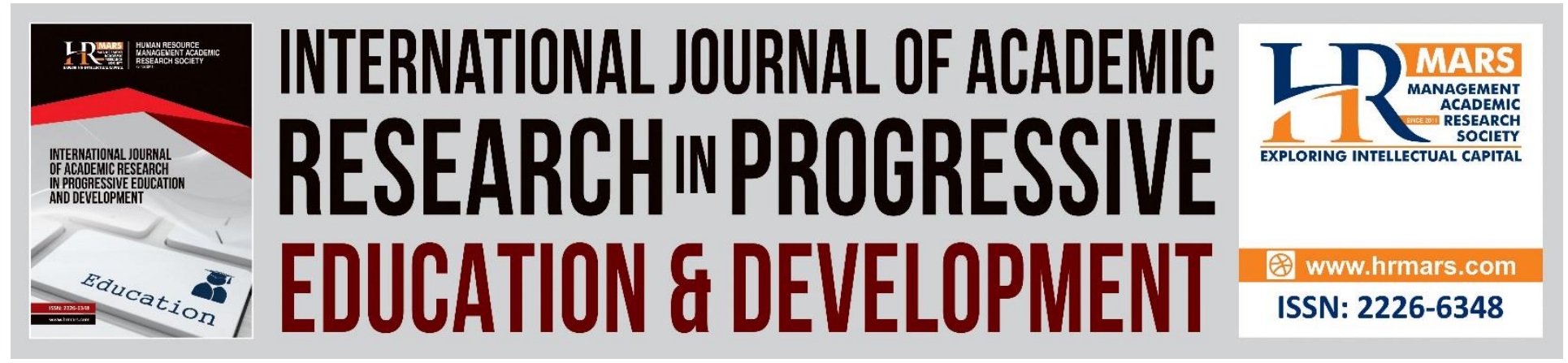

\title{
Learning Organizational Model in the 21th Century Classroom at Sultan Mahmud Science Secondary School in Terengganu, Malaysia
}

\author{
Mazni Salleh \\ Faculty of Islamic Contemporary Studies, Universiti Sultan Zainal Abidin, Malaysia \\ Aminuddin Jusoh \\ Faculty of Islamic Contemporary Studies, Universiti Sultan Zainal Abidin, Malaysia
}

Rahimah Embong

Faculty of Islamic Contemporary Studies /Faculty of General Studies \& Advanced Education, Universiti Sultan Zainal Abidin, Malaysia

\author{
Mustafa Mamat \\ Faculty of Informatics \& Computing, Universiti Sultan Zainal Abidin , Malaysia
}

\begin{abstract}
The 21st century is a period of turbulence, uncertainty, complexity and ambiguity, leading to effective leadership becoming more and more important. The strategies we use in education will soon become outdated and we need to generate new strategies to ensure that schools have credibility and continue to be relevant.. The study aims to build a model of learning organization in the 21st century classroom at SM Science Sultan Mahmud. The learning organization in this study refers to five core disciplines namely system thinking, personal mastery, mission sharing and vision, mental model and team learning that explain the importance of learning organization developed. Therefore, this study integrates learning organization disciplines to develop a learning organization model in the 21st century class at SESMA (MOP21-SESMA). The construction of this model is carried out by qualitative and quantitative methods. Data collection for the first phase is through semi structured interview methods. Data were analyzed using qualitative analysis methods. For the second phase the data are collected through a random sampling method. The interview findings were analyzed using qualitative methods involving the process of reducing, coding and categorizing data. Identified items are used to form questionnaires for second round sessions to build instruments. The process of analyzing data is run with the help of Statistic Package for the social Ver. 19 (SPSS 19). For Partial Least Square
\end{abstract}


INTERNATIONAL JOURNAL OF ACADEMIC RESEARCH IN PROGRESSIVE EDUCATION AND DEVELOPMENT

Vol. 7, No. 4, 2018, E-ISSN: 2226-6348 ๑ 2018 HRMARS

(SEM-PLS) descriptive analysis procedures to test the validity of the study variables, it developed the model of learning organization in the 21st century class at SM Science Sulltan Mahmud. The findings show that all dimensions are the dimensions of the organization's vision and mission, climate and organizational structure, 21st century organizational leadership, 21st century individual learning and 21st century collective learning culture have the accuracy of the fortunetellers. In conclusion, this study has produced a MOP21-SESMA model for guidance and indicators for school leaders to improve school performance, especially in schools in Malaysia.

Keywords: Learning Organization, 21st Century Classroom, Develop A Learning Organization Model

\section{Introduction}

As we move from one century to the next century, the only thing that is certain is change. Changes become important elements because demographics, societies, economics and lifestyle change over time. We may not be able to predict future scenarios accurately, but we need to be prepared to deal with them and the speed of action is immediately an important factor. As an educator, I tend to see an environment that is often changing. Education always accepts change and will continue to do so. This is important because students are the main asset of the country. Technological advances make education increasingly complex as students need change in line with their times. To achieve organizational goals, organizational leaders need to be open to three important steps: awareness of change, self-sufficiency to continue to lead the organization and lead change so that education continues to be relevant. Hence, to manage change in education in the 21st century, we need not only be a catalyst for change but lead to change in order to adapt and sustain and remain relevant.

The atmosphere in most existing organizations such as firms or school institutions emphasizes the task, discipline, strict procedures, strict rules of work and no space for creativity (Kline \& Saunders, 2010). An old management pattern with a pyramid power allocated to a small number of top managers has changed to co-operation, teamwork and equality considerations. Learning culture is a driving force in a learning organization that in turn ensures a holistic approach to developing human capital facing the 21st century. To survive this fierce competition, SESMA needs to make the Learning Organization dynamic and thinking forward. In other words, a paradigm shift needs to be done if SESMA wants to precede the competition in adapting to change. Existing organizational culture shows isolation and gap between top managers and subordinates that prevent learning from organization.

If scenarios are viewed at all schools, teachers work solely to ensure school excellence and creativity in solving tasks is limited. Some do not favor changes and reforms because they fear they cannot adapt to the new rules or they are forced to work harder. The educational profession is under pressure to improve student academic achievement, improve the quality of teaching and solve social illness problems in society. All of these elements provide a strong challenge to teaching leaders who want to create a fun and exciting climate and culture for their members and organizations to learn.

Based on the problems in schools, there is a need for SESMA to practice 21st century learning organizations in 21st century class. According to Senge (1990), an important feature in the shared vision is to facilitate communication and create an atmosphere of openness among 
INTERNATIONAL JOURNAL OF ACADEMIC RESEARCH IN PROGRESSIVE EDUCATION AND

DEVELOPMENT

Vol. 7, No. 4, 2018, E-ISSN: 2226-6348 ๑ 2018 HRMARS

members. In summary, it is a priority to implement change and renewal of the 21st century class to meet the challenges of this millennium.

\section{Problem Statement}

The interest of researchers on the concept of learning organization has led to many models and measurement tools to produce the concept (Marsick \& Watkins, 2003) in the organization. Among them are the models produced by Bui and Baruch (2010), Kenny (2006), Lam (2004), Marquardt (1996), Ortenblad (2004), Phillips (2003), Silins, Zarins and Mulford (2002) (2005). However, some of these models and measurement tools were constructed based on local contexts that were not suitable for other cultural or state contexts (Alavi \& McCormick, 2004) such as model and strategy examples by Voulalas and Sharpe (2005) as well as Tan (2000). The model has elements of staff selection (teachers) that do not occur in the context of Malaysian schools.

In addition, the absence of a model in line with the practice of learning organizations in Malaysia has also led local researchers to adopt strategies and practices developed by foreign researchers (Shahrin, 2000; Jassa, 2000; Salleha Abd Kahar, 2001; Sing, 2002; Mahani Mokhtar , 2002; Mohd Noor Hisham Mohd Haron, 2004; Zulkifli Ab Rahman, 2006; Noor Azam Abd Aziz, 2008; Zamri Kamarudin, 2009; Yusof Boon \& Fadzlon Hassan, 2011; Based on this issue, Harris (2011) asserted that his view that borrowing a strategy or practice that did not fit into a context would not be of benefit to the organization. Model construction should be in line with the needs of the organization as well as to illustrate strategies or practices that are relevant to the needs (Cavaleri, 2008).

Hence, the development of a 21st-century learning organization model for SESMA is an effort to produce a guideline on implementing a 21st-century learning organization of practice in the context of the school. The model is expected to give a clear picture of the practice of 21st century learning organizations that are relevant to the context of the 21st century class to build a learning culture within the organization. Furthermore, the 21st century class model at SESMA can be adapted to other local researchers as items or instruments for building a model or measurement tool that is more in keeping with the cultural context and practice of schools in Malaysia. This study is conducted to answer the following questions: i. What are the characteristics of the 21st century at SM Sultan Mahmud? ii. What is the change in the 21st century classroom in SESMA? iii. How to change the behavior of teachers in the 21st Century Classroom at SESMA. Generally, this study is conducted to achieve the following objectives: i. The characteristics of the 21st century classroom at SESMA. ii. Identifying Changes in the 21st century classroom at SESMA. iii. Identifying the Change of teacher behavior in the 21st Century Class.

\section{Materials and Methods}

This study was conducted to form one to three students at SM Sultan Mahmud. The limitation, it is not able to measure the changes in class and behavior of teachers teaching in form four and five as well as other school students.

This study provides empirical evidence and confirms the suitability of Learning Organizations in the 21st century class constructed for use in SESMA's social and cultural contexts. The Learning Organization's dimensions may be adopted by other researchers as a framework of study theory and as a 21st-century model in another school. 
INTERNATIONAL JOURNAL OF ACADEMIC RESEARCH IN PROGRESSIVE EDUCATION AND

DEVELOPMENT

Vol. 7, No. 4, 2018, E-ISSN: 2226-6348 ๑ 2018 HRMARS

Subsequently, the construction of this model is also in line with the main focus of the Malaysia Education Blueprint 2013-2025. Implementing consistent practice of continuous learning in all schools will enhance teacher professionalism and continuous leadership performance. Hence, the government's intention in the third wave (2021-2025) - school, teachers and school leadership - performs above the minimum standard in the next eight years to be achieved more easily.

The questionnaire and interview methods were used in this research, by collecting data from the research group. To answer the study questions, several methods have been designed to meet the needs of this study. Researchers used interviews to find out the characteristics of the 21st century class at SESMA. Interview questions were analyzed using thematic techniques and obtained consent on the characteristics of the 21st century class at SESMA. Since the selection of study participants will influence the quality of the study (Worrell, Di Gangi \& Bush, 2012), Hsu and Sandford (2007) recommend that the expert panel of the study be chosen among those with expertise in the field studied, capable and willing to engage in Study and have the skills to communicate. Hence, interview questions are made to SESMA teachers and students to ensure that the findings are appropriate to the needs of the 21st century class at SESMA. Next, the questionnaire was distributed to answer the question whether there is a change in the 21st century classroom in SESMA and there is a change in teacher behavior in the 21st century class at SESMA. The source of the questionnaire was adapted based on previous studies such as table 1 shown.

Table 1 Source of study instrument

\begin{tabular}{|c|c|c|}
\hline Construct & $\begin{array}{l}\text { No of } \\
\text { Item }\end{array}$ & Source \\
\hline $\begin{array}{l}\text { Dimensions Vision and } \\
\text { mission of the organization }\end{array}$ & 5 & $\begin{array}{l}\text { Maquardt, M. } 2002 \text { Building the learning } \\
\text { organization. Mastering the } 5 \text { elements for } \\
\text { corporate learning. 2nd Ed. Palo Alto : Davies-Black } \\
\text { (pp.237-41) }\end{array}$ \\
\hline $\begin{array}{l}\text { Climate dimension and } \\
\text { organizational structure }\end{array}$ & 5 & $\begin{array}{l}\text { Sharma, S. 2005. A Framework for building a } \\
\text { learning Organization in the } 21 \text { st Century. } \\
\text { International Journal of Innovation and learning. }\end{array}$ \\
\hline $\begin{array}{l}\text { Dimensions of } \\
\text { organizational leadership } \\
\text { of the } 21 \text { st century }\end{array}$ & 7 & $\begin{array}{l}\text { Maquardt, M. 2002. Building the learning } \\
\text { organization. Mastering the } 5 \text { elements for } \\
\text { corporate learning. 2nd Ed. Palo Alto : Davies-Black } \\
\text { (pp.237-41) }\end{array}$ \\
\hline $\begin{array}{l}\text { 21st Century Individual } \\
\text { Learning Dimensions }\end{array}$ & 16 & $\begin{array}{l}\text { Pettinggar (2015). Importance of Learning } \\
\text { Organization in the 21st Century. International } \\
\text { Journal of Innovation and learning. }\end{array}$ \\
\hline $\begin{array}{l}\text { 21st century classroom } \\
\text { learning dimension }\end{array}$ & 15 & $\begin{array}{l}\text { Pettinggar (2015). Importance of Learning } \\
\text { Organization in the 21st Century. International } \\
\text { Journal of Innovation and learning. }\end{array}$ \\
\hline & 48 & \\
\hline
\end{tabular}


INTERNATIONAL JOURNAL OF ACADEMIC RESEARCH IN PROGRESSIVE EDUCATION AND DEVELOPMENT

Vol. 7, No. 4, 2018, E-ISSN: 2226-6348 @ 2018 HRMARS

The method of collecting data using a questionnaire is an efficient method of collecting large amounts of data at a low cost and in a short period of time (Richardson et al., 2005). Questionnaires were returned within seven to 30 days from the date of distribution. However, not all questionnaires are returned in real terms. A total of 42 questionnaires were returned from 55 units distributed to 55 teachers in SESMA. Therefore, the return rate of the questionnaire is 76.36 percent. This repayment rate meets the demands of Creswell's statement (2008) that most studies in major educational journals report rates of returns over fifty percent.

The research data to answer the question whether there is a change in the 21st century class at SESMA and how the changes in teacher behavior in the 21st century class at SESMA were analyzed using the SMART PLS 3.0 software. This study chose to use the Partial Lease Square Structural Model approach based on complex structured models (Ohana and Meyer, 2010; Urbach, Smolnik, and Riempp, 2010), a focus on predictions (Hair et al., 2014) And abnormal data (Aibinu and Al-Lawati, 2010; Zhang, Guo, and Chen, 2007).

PLS is also capable of analyzing smaller data and from various data categories (Leidner, Lo \& Preston, 2011) and data with multicollinearity problems (Farahani et al., 2010).

\section{Analysis and Findings}

The main purpose of this study is to identify the features of the 21st century class at SESMA, the changes in the 21st century class and the change in teacher behavior in the 21st century class at SESMA. 
INTERNATIONAL JOURNAL OF ACADEMIC RESEARCH IN PROGRESSIVE EDUCATION AND

DEVELOPMENT

Vol. 7, No. 4, 2018, E-ISSN: $2226-6348$ @ 2018 HRMARS

\section{Features of the 21st century SESMA class}

To answer this questionnaire closed questionnaire was conducted on 27 teachers. The findings are as follows:

Table 2: Characteristics of the 21st century class at SESMA

\section{No Closed question construct}

1 Teacher is a facilitator for student learning and creators to a productive classroom environment of the 21st century The collaborative project-based curriculum used in the 21st

2 century class aims at developing high-level thinking skills and effective communication skills that students need

3 The use of technology is a 21st Century classifier The 21st century classroom focusing on conducive

4 collaborative space sets it apart from the 20th century classroom

Single subject teaching at a time was the norm in the past

5 and today the lesson is to apply multiple disciplines in all subjects

6

Focusing students - laying interest in importance, teacher as mentor

Mutual respect

- need respect for teachers and students

- teachers need to encourage students to speak

7 confidently and value their opinions

- students need to learn to cooperate and respect classmates

8

Self-learning - Classes can still work with different levels of learning

Students are responsible for their learning - if students are

9 encouraged to actively participate in learning, then they will be more responsible with their learning

Assessment based on achievement - Teachers are always

10 evaluating with various methods without being bound by a form of testing alone.
Number

of

approvals

27

27

100

27

100

27

100

25

92.5

26

24

88.9

26

24

88.9

25

92.5

The findings of the closed response questionnaire from 27 teachers teaching form 1,2 and 3 at SESMA found that $100 \%$ consent were all 27 teachers for construct 1, 2, 3 and 4 . While the construct of 5 to 10 levels of agreement on the characteristics of class - 21 in SESMA between 88 to $92 \%$, which is still at a high level. The study found that all the 10 contracts that were presented as a feature of the 21st century class at SESMA were high. 
INTERNATIONAL JOURNAL OF ACADEMIC RESEARCH IN PROGRESSIVE EDUCATION AND DEVELOPMENT

Vol. 7, No. 4, 2018, E-ISSN: $2226-6348$ @ 2018 HRMARS

\section{Identify the changes in the 21st century class and identify the changing behavior of teachers in the 21st century class at SESMA}

This section will discuss the findings of the structural model to answer the question of whether there is a change in the 21st century class and identify changes in teacher behavior in the 21st century class at SESMA. In testing the measurement model, the items of the study will be tested to the extent of its accuracy in representing a construct, thereby ensuring that the research items meet the standards of reliability and reliability. Guidelines for testing the measurement model are based on Straub, Boudreau, and Gefen (2005). Testing of the measurement model involves internal consistency, consistency of construct validity, which involves the validity of convergence and discrimination as described below. Prior to that, the study also conducted tests to determine the factor structure known as exploratory factor analysis (Hair et al., 2014).

Based on table 3 below, According to Urbach et al. (2010) the traditional method of validity testing is to use alpha Cronbach. Through this method, high alpha values indicate that items in a particular construct have the same meaning and value in explaining a construct (Cronbach, 1951). The alternative to the use of alpha Cronbach is the reliability of composites (Werts et. all, 1974). The use of composite reliability was suggested by Chin (2009) to address some of the shortcomings in the measurement using Alfa Cronbach. Internal validity value is the factor loading factor in the above constructs above 0.7. In this study, alpha Cronbach values are between 0.755 and 0.928 , The use of Rho_A reliability coefficients ranges from 0.760 to 0.935 and composite reliability between 0.866 and 0.943 ie all constructs above the minimum value of 0.70 are shown in the table indicating internal validity and consistency in indicators such as Has been set by Nunally and Bernstein (1994) and Hair (2014).

Subsequent constructs were made, by measuring the value of AVE (average variance extracted) as suggested by Fornell and Larcker (1981). In addition to AVE values, convergence validity is also judged by the value of composite reliability. If the value of the composite reliability exceeds 0.8 (Nunally and Bernstein, 1994), then the instrument of this study achieves convergent

validity standards. Furthermore, the factor loading factor exceeding 0.7 also proves that the instrument of this study achieves convergent validity standards (Fornell and Larcker, 1981). 
Table 3: Internal validity

\begin{tabular}{|c|c|c|c|}
\hline Construct & $\begin{array}{c}\text { Alpha } \\
\text { Cronbach's }\end{array}$ & rho_A & $\begin{array}{l}\text { Composite } \\
\text { Relibility }\end{array}$ \\
\hline The 21st century classroom is a student-centered, non-centered teacher & 0.909 & 0.911 & 0.943 \\
\hline $\begin{array}{l}\text { Students are no longer learning each subject separately. Instead, they work } \\
\text { through interdisciplinary projects that use information and skills from various } \\
\text { subjects and demonstrate some of the most important academic standards. } \\
\text { Textbooks are not the main source of information. Students use a variety of } \\
\text { resources, including technology to find and collect the information they } \\
\text { need. Examples, journals, expert interviews, exploring the internet or using } \\
\text { computer software programs. } \\
\text { Group of pupils formed flexibly according to individual needs is the norm. }\end{array}$ & 0.880 & 0.760 & 0.866 \\
\hline $\begin{array}{l}\text { The teacher assesses the teaching needs of pupils and learning styles and } \\
\text { then leverages various teaching and learning methods to meet the needs } \\
\text { of all students in the classroom. }\end{array}$ & 0.849 & 0.853 & 0.899 \\
\hline $\begin{array}{l}\text { The focus of student learning in this class is different. Focus is no longer } \\
\text { on learning by memorizing and remembering information but learning } \\
\text { how to learn. Now, students use the information they have learned and } \\
\text { demonstrate their mastery of content in the projects they are working on }\end{array}$ & 0.914 & 0.926 & 0.941 \\
\hline $\begin{array}{l}\text { Teachers use a variety of performance-based assessments to assess } \\
\text { student learning. Tests that measure the ability of students to memorize } \\
\text { and remember facts are no longer the only way to assess student learning }\end{array}$ & 0.856 & 0.864 & 0.913 \\
\hline $\begin{array}{l}\text { The aim of the 21st century classroom is to provide students with the } \\
\text { ability to be productive in the workplace. }\end{array}$ & 0.928 & 0.935 & 0.943 \\
\hline $\begin{array}{l}\text { Create a safe, supportive, and positive learning environment for all students. This } \\
\text { requires planning on the part of the teacher to avoid security risks, to create a room } \\
\text { layout that supports learning and to provide access to special needs students }\end{array}$ & 0.924 & 0.925 & 0.938 \\
\hline Designing for long-term and short-term. & 0.894 & 0.895 & 0.926 \\
\hline $\begin{array}{l}\text { Foster collaboration among students in the classroom. Teachers are examples and } \\
\text { promotes important values and processes in the real world of democracy }\end{array}$ & 0.876 & 0.879 & 0.924 \\
\hline Encourage students' inner curiosity and motivation to learn. & 0.889 & 0.890 & 0.947 \\
\hline $\begin{array}{l}\text { Teachers help students become self-reliant, creative and critical thinkers by } \\
\text { providing the experience that develops students to be independent, } \\
\text { creative and critical thinking and skills solving problems }\end{array}$ & 0.929 & 0.933 & 0.950 \\
\hline $\begin{array}{l}\text { Using language to foster self-expression, identity development and learning } \\
\text { among students. }\end{array}$ & 0.901 & 0.903 & 0.931 \\
\hline Listen carefully and responsive. & 0.960 & 0.964 & 0.969 \\
\hline Foster awareness and cultural sensitivities within the self. & 0.925 & 0.928 & 0.940 \\
\hline
\end{tabular}

As set out in Table 4 below, all study constructs exceed the prescribed value while verifying that each construct meets the convergence validity standards. 
INTERNATIONAL JOURNAL OF ACADEMIC RESEARCH IN PROGRESSIVE EDUCATION AND

DEVELOPMENT

Vol. 7, No. 4, 2018, E-ISSN: $2226-6348 @ 2018$ HRMARS

Table 4: The validity of Constructs for convergence validity

\begin{tabular}{ll}
\hline \multicolumn{1}{c}{ construct } & Average Variance Extracted (AVE) \\
\hline 21st century classroom learning dimension & 0.940 \\
Climate dimension and organizational structure & 0.894 \\
Dimensions of organizational leadership of the 21st century & 0.837 \\
21st Century Individual Learning Dimensions & 0.927 \\
Vision and mission of the organization & 0.949 \\
\hline
\end{tabular}

Citizenship test for the model of learning organization in the 21st century class at SM Science Sultan Mahmud

A significant testing was carried out to determine the approximate relationship between the study variables to answer the hypotheses of the research proposed by the researcher. The coefficient value is between -1 (negative) and +1 (positive). The coefficient of approximation of +1 (positive) indicates that the variable has a very strong positive relation and if the coefficient value close to -1 (negative) indicates that the variable has a very strong negative relationship. The method that can be used to determine the significance of relationships between variables is by comparing the critical $t$ values with the $t$ statistic values. If the statistic $t$ value is greater than the critical value, then the variables of the study variables are significant at a certain probability error (error probability). Therefore, in this study researchers are using Hair et al. (2014) recommendations to calculate and determine the significant value by using the bootstrapping method (Hair et al., 2014).

Table 4.4 below illustrates the results of hypothesis testing through direct effects in P-values, Tvalues and standard deviations. Of the ten hypotheses, the direct effects predict three unimportant band analysis i.e. climate and organizational structure with 21st century collective learning culture, climate structure and organization with individual learning 21st century and 21st century organizational leadership with climate and structure. Values $0.9,0.2$ and 0.9 which do not meet the requirements of $P<0.05$ and then show negative and non-significant relationship 0.003 with $p<0.05$. However, seven other hypotheses showed a positive and significant relationship i.e. $\mathrm{P}<0.05$ further supported the test as shown in table 4.4 below.

The results of this test indicate the overall model corresponds to the data or it may reflect the reality and the phenomenon in the field. Therefore, the results of this study can be valid and reliable. The results of the analysis show that all legitimate and reliable indicator variables reflect the latent order with model testing yielding the appropriate model conclusions. Partial test results show that all exogenous variables have significant effects on endogenous variables. This means that the validity of discrimination can be proven in the measurement model of this study. 
INTERNATIONAL JOURNAL OF ACADEMIC RESEARCH IN PROGRESSIVE EDUCATION AND

DEVELOPMENT

Vol. 7, No. 4, 2018, E-ISSN: $2226-6348$ @ 2018 HRMARS

Table 5: Hypothesis Testing - Direct Impact

\begin{tabular}{|c|c|c|c|c|c|}
\hline Path Regression & $\begin{array}{l}\text { Original } \\
\text { Sample } \\
(0)\end{array}$ & $\begin{array}{l}\text { Standard } \\
\text { deviation } \\
\text { (STDEV) }\end{array}$ & $\begin{array}{l}\text { T Statistics } \\
(|\mathrm{O} / \mathrm{STDEV}|)\end{array}$ & $P$ value & Result \\
\hline 21st Century COLLEGE LEARNING & & & & & \\
\hline $\begin{array}{l}\text { CULTURAL HERITAGE } \rightarrow \text { 21st } \\
\text { Century INDIVIDUAL LEARNING }\end{array}$ & 0.323 & 0.110 & 2.923 & 0.003 & Supported \\
\hline $\begin{array}{l}\text { Climate and organizational } \\
\text { structure } \rightarrow \text { culture collective } \\
\text { learning the } 21 \text { st century }\end{array}$ & 0.013 & 0.205 & 0.064 & 0.949 & Not Supported \\
\hline $\begin{array}{l}\text { Climate and organization } \rightarrow \text { the } \\
\text { individual learning the } 21 \text { st century }\end{array}$ & -0.130 & 0.102 & 1.264 & 0.206 & Not Supported \\
\hline $\begin{array}{l}\text { Leadership organization of the } 21 \text { st } \\
\text { century } \rightarrow>\text { culture collective } \\
\text { learning the } 21 \text { st century }\end{array}$ & 0.465 & 0.209 & 2.224 & 0.026 & Supported \\
\hline $\begin{array}{l}\text { Leadership } \\
\text { leadership } \rightarrow \quad \text { crganizational } \\
\text { climate and }\end{array}$ & 0.012 & 0.116 & 0.103 & 0.918 & Not Supported \\
\hline organization structures & & & & & \\
\hline $\begin{array}{l}\text { Leadership organization of the } 21 \text { st } \\
\text { century } \rightarrow>\text { individual learning the } \\
21 \text { st century }\end{array}$ & 0.220 & 0.065 & 3.389 & 0.001 & Supported \\
\hline Leadership organizational & & & & & \\
\hline $\begin{array}{l}\text { leadership -> vision and mission of } \\
\text { organization }\end{array}$ & 0.850 & 0.296 & 2.876 & 0.004 & Supported \\
\hline Vision And Mission Of Organization & & & & & \\
\hline $\begin{array}{l}\text {-> 21th ABAD College Cultural } \\
\text { Culture }\end{array}$ & 0.479 & 0.252 & 1.902 & 0.057 & Supported \\
\hline $\begin{array}{l}\text { Vision and mission organization -> } \\
\text { organization climate and structure }\end{array}$ & 0.900 & 0.129 & 6.998 & 0.000 & Supported \\
\hline $\begin{array}{l}\text { Vision and mission organization -> } \\
\text { the individual learning the } 21 \text { st } \\
\text { century }\end{array}$ & 0.596 & 0.172 & 3.457 & 0.001 & Supported \\
\hline
\end{tabular}

\section{Discussions and Conclusions}

Learning Organization Discovery in the 21st century classroom at SESMA is in line with this study. It is therefore possible to discuss and conclude that the Learning Organization in the 21st century classroom at SESMA is as intended.

\section{Features of the 21st Century Classroom at SESMA}

As we move further into the new millennium, it is clear that class needs in the 21st century are very different from the needs of classes in the 20th class. In the 21st century classroom, teachers are student learning facilitators and creators in productive classroom environments where pupils can develop the skills they need at work in the future.

The focus of the 21st century classroom is where students can experience the environment as they will become workers in the 21st century. The project-based curriculum used in the classroom is intended to develop high-minded skills, effective communication skills, and the technological knowledge required by students in the workplace in the 21 st century. 
The features of the 21st century classroom focus on the collaborative space that distinguishes it from the 20th grade. The teaching of a single subject at one time is a custom in the past and today the lesson is to apply a variety of disciplines in all subjects

The 20th century teaching strategy is no longer effective. Teachers must practice new teaching strategies that differ from those working in the 20th class. This curriculum must be more relevant to what the student can experience at work in the 21st century.

\section{Change in Classroom}

The 21st century room is a student-centered teacher, not centered. Teachers no longer function as lecturers but as facilitators of learning. Students learn by doing and teachers act as facilitators to help pupils when they work with their projects. Students learn to use investigative methods (questions) and collaborate with others. The smallest real world they experience as soon as they leave the class.

Students are no longer learning each subject separately. Instead, they work through interdisciplinary projects that use information and skills from various subjects and demonstrate some of the most important academic standards. For example, books given in reading or English, are set as examined in social studies. The final reading of UK book reports may require special social studies standards to be met.

Textbooks are no longer the main source of information. Students use a variety of resources, including technology to find and collect the information they need. They can get journals, interview specialists, explore the internet or use computer software programs to use what they learn or search for information. Not only for special projects, technology is used in an integrated way every day.

In this new class, a group of students formed flexibly according to individual needs is the norm. Teachers still use instructions to the whole group, but no longer the primary teaching method used. Teachers assess the need for teaching students and learning styles and then leveraging on various teaching and learning methods to meet their needs

he focus of student learning in this class is different. Focus is no longer on learning by memorizing and remembering information but learning how to learn. Now, students use the information they have learned and demonstrate their mastery of content in the projects they are working on. Pupils learn how to ask the right questions, how to conduct appropriate investigations, how to find answers, and how to use information. The emphasis in the classroom is to create those who are lifelong learners. With this goal in mind, students move beyond the role of a student learning through real-world experiences.

As pupil learning has changed as well as learning assessment. Teachers use a variety of performance-based assessments to assess student learning. Tests that measure the ability of students to memorize and remember facts are no longer the only way to evaluate student 
INTERNATIONAL JOURNAL OF ACADEMIC RESEARCH IN PROGRESSIVE EDUCATION AND

DEVELOPMENT

Vol. 7, No. 4, 2018, E-ISSN: 2226-6348 ๑ 2018 HRMARS

learning. On the other hand, teachers use student projects, presentations, and other performance-based assessments to determine student achievement and needs.

The aim of the 21st century classroom is to provide students with the ability to be productive in the workplace.

\section{Change in Teacher Behavior}

Just as the classroom has changed, so does the teacher adjust their roles and responsibilities. Teachers are no longer teaching separately. They are now co-teaching, teaching in teams, and working with other members of the department. Teachers are not the only ones responsible for student learning. Holders include administrators, board members, parents, students and all sharing responsibilities with teachers to educate students.

Teachers know that they must involve students in learning and provide effective teaching using various teaching methods as well as technology. To do this, teachers need to keep up to date on what's going on in the field. As people who are lifelong learners, they are active participants in their own learning. They are looking for things related to professional development that helps them to improve student learning and their performance.

The new role of teachers in the 21st century classroom requires a change in knowledge and behavior in the classroom. Teachers need to know how to:

The aim of the 21st century classroom is to provide students with the ability to be productive in the workplace.

i. Teachers along with their students and know how to take steps in learning and providing meaningful work that involve students actively in their learning.

ii. Create a safe, supportive, and positive learning environment for all students. This requires planning on the part of the teacher to avoid security risks, to create a room layout that supports learning and to provide access to special needs students. Teachers are skilled in managing diverse learning experiences to create positive and productive learning environments for all students in the classroom. Classroom procedures and policies are an important part of creating a positive learning environment. Teachers evaluate and implement effective classroom management techniques in a consistent manner. He uses daily routines and procedures that maximize teaching time. Students know what to expect from them, and teachers who know how to handle the disruption effectively so that there is no adverse effect on student teaching time.

iii. Designing for long-term and short-term.

iv. Foster collaboration among students in the classroom. Teachers are examples and promotes important values and processes in the real world of democracy.

v. Encourage students' inner curiosity and motivation to learn.

vi. Teachers help students become self-reliant, creative and critical thinkers by providing experiences that develop students to be self-reliant, creative and critical thinking and skill-solving problems. Teachers give enough time for students to complete tasks, and are clear about his expectations. Pupils are actively involved in their own learning in an 
INTERNATIONAL JOURNAL OF ACADEMIC RESEARCH IN PROGRESSIVE EDUCATION AND

DEVELOPMENT

Vol. 7, No. 4, 2018, E-ISSN: 2226-6348 @ 2018 HRMARS

environment that respects the unique needs of their development and promotes positive expectation and mutual respect.

vii. Make the student feel appreciated. Teachers emphasize cooperative group effort rather than competitive individual efforts through collaborative projects and teamwork.

viii. Communicate effectively with pupils, parents, friends, and other stakeholders. Teachers use written, verbal, and technological communications to realize the experience of the buyer

ix. Use language to foster self-expression, identity development and learning among students.

x. Listen carefully and responsive.

xi. Foster awareness and cultural sensitivities in his / her students. Teachers encourage pupils to learn about other cultures and instill in their students the respect of others and their differences.

\section{Conclusion}

If pupils want to become productive experts in the work of the 21st century, they must move beyond the 20th century skills and master the skills of the 21st century. Teachers are entrusted with the mastery of this skill, as well as being a model of this skill in the classroom. The 21st century classroom features will be very different from those in the classroom as they focus on delivering high-performance students, effective communicators, creative thinkers, and technologists.

\section{Acknowledgement}

The authors acknowledge the Ministry of Education for funding the student's study under Program My Brain15. We also thank to Research Management, Innovation \& Commercialization Centre (RIMC), UniSZA, and Malaysian Ministry of Education for supporting our research project of Fundamental Research Grant Scheme (FRGS/1/2015/SS109/UNISZA/02/1).

\section{Corresponding Author}

Dr. Rahimah Embong, PhD. is Associate Professor at Department of Education, Dakwah \& Islamic Civilization at Faculty of Islamic Contemporary Studies as well as Deputy Dean (Students' Affairs

\& Alumi), Faculty of General Studies \& Advanced Education at Universiti Sultan Zainal Abidin (UniSZA), Gong Badak Campus, 21300 Kuala Nerus. Terengganu, Malaysia.

Email: rahimahembong@unisza.edu.my

\section{References}

Alavi, S. B., \& McCormick, J. (2004). A Cross-Cultural Analysis of The Effectiveness of The Learning Organization Model in School Contexts. The International Journal of Educational Management, 18(7), 408-416.

Albinu \& Al-Lawati (2010) Using PLS-SEM technique to model construction organizations willingness to participate in e-biding automation construction, 19(6), 714-724

Bui, H., \& Baruch, Y. (2010). Creating Learning Organizations: A Systems Perspective. The Learning Organization, 17(3), 208-227. 
INTERNATIONAL JOURNAL OF ACADEMIC RESEARCH IN PROGRESSIVE EDUCATION AND

DEVELOPMENT

Vol. 7, No. 4, 2018, E-ISSN: $2226-6348 @ 2018$ HRMARS

Cavaleri, S. (2008). Are Learning Organizations Pragmatic? The Learning Organization, 15(6), 474-485.

Chin, H. L. (2009). Pembangunan Dan Penilaian Laman Portal Pembelajaran Tatabahasa Bahasa Melayu Tingkatan Dua (Disertasi ijazah kedoktoran yang tidak diterbitkan). Universiti Malaya, Kuala Lumpur.

Creswell, J. W. (2008). Educational Research: Planning, Conducting, and Evaluating Quantitative and Qualitative Research (3rd Ed.). New Jersey: Pearson Prentice Hall.

Cronbach, L. J. (1951). Coefficient alpha and the internal structure of tests. Psychometrika, 16, 297-334 (28,307 citations in Google Scholar as of 4/1/2016).

Farahani, Rahiminejad, V., Hajiqanbar, H., Khaustov, A.A. \& Talebi, A.A. (2015) A new genus and two new species of the family Pygmephoridae. Annales of the Entomological Society of America, 108(5), 893-901.

Fornell, C., \& Larcker, D. F. (1981). Structural equation models with unobservable variables and Great River Books.

Hair, J. F., Ringle, C. M., \& Sarstedt, M. (2014). PLS-SEM: Indeed a silver bullet. The Journal of Marketing Theory and Practice, 19(2), 139-152.

Harris, A. (2011). System Improvement Through Collective Capacity Building. Journal of Educational Administration, 49(6), 624-636.

Hsu, C. C., \& Sandford, B. A. (2007). The Delphi technique: Making senses of consensus. Practical Assessment, Research \& Evaluation, 12(10). Retrieved from http://pareonline.net/getv.asp?v=12\&n=10

Jassa, I. (2000). Amalan Organisasi Pembelajaran di Universiti Utara Malaysia dari perspektif kakitangan (Tesis sarjana yang tidak diterbitkan). Universiti Utara Malaysia, Kedah. kedoktoran yang tidak diterbitkan). Universiti Putra Malaysia, Selangor.

Kenny, J. (2006). Strategy And The Learning Organization: A Maturity Model for The Formation of Strategy. The Learning Organization, 13(4), 353-368.

Kline, P., and Saunders, B. (2010). Ten steps to a learning organization. New York:

Lam, Y. L. J. (2004). Reconceptualizing A Dynamic Model of Organizational Learning For Schools. Journal of Educational Management, 42(3), 297-311.

Leidner, D. E., Lo, J., \& Preston, D. (2011). An empirical investigation of the relationship of IS strategy with firm performance. Journal of Strategic Information Systems, 20(4), 419437. 
INTERNATIONAL JOURNAL OF ACADEMIC RESEARCH IN PROGRESSIVE EDUCATION AND

DEVELOPMENT

Vol. 7, No. 4, 2018, E-ISSN: 2226-6348 @ 2018 HRMARS

Mahani Mokhtar. (2002). Kesediaan Sekolah Menjadi Organisasi Pembelajaran (Tesis sarjana yang tidak diterbitkan). Universiti Teknologi Malaysia

Marquardt, M. J. (1996). Building the learning organization: A systems approach to quantum improvement. New York: Mc Graw-Hill.

Marsick, V. J., \& Watkins, K. E. (2003). Demonstrating the value of an organization's learning culture: The Dimensions of the Learning Questionnaire (DLOQ). Advances in Developing Human Resources, 5(2), 132-151.

measurement error. Journal of Marketing Research, 18(1), 39- 50

Nunnally, J. C., \& Bernstein, I. H. (1994). Psychometric theory (3rd ed.). New York, NY: McGraw-Hill, Inc.

Ohana, M., \& Meyer, M. (2010). Should I stay or should I go now? Social enterprises permanent Ortenblad, A. (2004). The Learning Organization: Towards An Integrated Model. The Learning Organization, 11(2), 129-144.

Phillips, B.T. (2003). A Four-Level Learning Organization Benchmark Implementation Model. The Learning Organization, 10(2), 98-105

Richardson, S., Guru, B. K., Cheng, M. Y., Khong, K. W., \& Pointon, L. (2005). How to Research: A Guide for Undergraduate \& Graduate Students. Singapore: Thomson Learning

Salleha Abd. Kahar. (2001). Ke Arah Organisasi Pembelajaran (Tesis sarjana yang tidak diterbitkan). Universiti Teknologi Malaysia, Johor.

Senge, P. M. (1990). The fifth discipline: The art and practice of the learning organization. New York: Doubleday.

Shahrin, H. (2000). Universiti Teknologi Malaysia ke arah sebuah organisasi pembelajaran (Tesis sarjana yang tidak diterbitkan). Universiti Teknologi Malaysia, Johor.

Silins, H., Zarins, S., \& Mulford, B. (2002). What Characteristics and Processes Define A School as A Learning Organization? Is this is a useful concept to apply to school. International Education Journal, 3(1), 24-32

Sing, S. K. (2002). Learning Organization Practices: A Comparative Study Between Multinationals and Local Companies (Tesis sarjana yang tidak diterbitkan). Universiti Multimedia, Kula Lumpur.

staff's intention to quit in a changing environment. European Management Journal, 28, 441-454.

Straub, D. Gefen, D., (2005). A practical guide to factorial validity using PLS- Graph: Tutorial and annotated example. Communications of the Association for Information Systems, 16(1), 
INTERNATIONAL JOURNAL OF ACADEMIC RESEARCH IN PROGRESSIVE EDUCATION AND

DEVELOPMENT

Vol. 7, No. 4, 2018, E-ISSN: $2226-6348$ @ 2018 HRMARS

91-109

structural assumptions. Education and Psychological Measurement, 34, 25-33. doi:10.1177/001316447403400104

Tan, C. Y. (2000). High-Performance Human Resource Strategies in Learning School. The Learning Organization, 7(1), 32-39.

Urbach, N., Smolnik, S., \& Riempp, G. (2010). An empirical investigation of employee portal success. The Journal of Strategic Information Systems,19(3), 184-206.

Voulalas Z. D., \& Sharpe, F. G. (2005). Creating schools as learning communities: Obstacles and processes. Journal of Educational Administration, 43(2), 187-208.

Werts, C. E., Linn, R. L., \& Joreskog, K. G. (1974). Interclass reliability estimates: Testing

Worrell, J., Di Gangi, P. M., \& Bush, a. A. (2012). Exploring the use of the Delphi method in accounting information system research. International Journal of Information System, doi:10.1016/j.accinf.2012.03.03

Boon, Y., \& Hassan, F. (2011). Tahap Amalan Organisasi Pembelajaran di Sebuah Sekolah Menengah Daerah Kulaijaya, Johor. Journal of Educational Management, (December 2011), 18-33

Zhang, J. W., Hong, H. Y., Scardamalia, M., Teo C. L., \& Morley, E. A. (2011). Sustaining Knowledge Building as A Principal-Based Innovation at An Elementary School. Journal of The learning Sciences, 20(2), 262-307

Rahman, Z. A. (2006). Pengaruh Organisasi Pembelajaran Terhadap Kecemerlangan Organisasi: Satu Kajian Persepsi di Kalangan Kakitangan Maktab Rendah Sains Mara (Disertasi ijazah kedoktoran yang tidak diterbitkan). Universiti Malaysia Terengganu, Terengganu 